\title{
ANALYSIS OF THE INFLUENCE OF CAPITAL LABOUR INTENSIVE, INVESTMENT, MANAGERIAL OWNERSHIP, OPERATING LEVERAGE THROUGH DIVIDEND AND FINANCIAL LEVERAGE AS INTERVENING VARIABLE ON FIRM VALUE IN INDONESIA NON FINANCIAL SECTOR COMPANIES
}

\author{
Robi Nugraha \\ PT GMF AeroAsia \\ Email: robikerja@yahoo.com
}

\begin{abstract}
The purpose of this study was to analyze the influence of capital labour intensive, investment, managerial ownership, operating leverage, dividend and financial leverage on the firm value of Indonesia non financial sector companies, the influence of capital labour intensive, investment, managerial ownership, operating leverage variable on dividend and financial leverage of Indonesia non financial sector companies, and the influence of capital labour intensive, investment, managerial ownership, operating leverage variable on the firm value through dividend and financial leverage as intervening variable. The results show that the capital labour intensive, investment, managerial ownership, operating leverage, dividend and financial leverage have significant influences on the firm value of Indonesia non financial sector companies. The capital labour intensive, investment, managerial ownership, operating leverage variable do not have significant influences on dividend. The capital labour intensive, investment, managerial ownership, operating leverage variable have significant influences on financial leverage. With path analysis, the result show the The capital labour intensive, investment, managerial ownership, operating leverage variable do not have significant influence on the firm value of Indonesia non financial sector companies with dividend and financial leverage as intervening variable.
\end{abstract}

Keywords: Capital Labour Intensive, Investment, Managerial Ownership, Operating Leverage, Dividend and Financial Leverage, Firm Value. 
Jurnal Riset Manajemen Sains Indonesia (JRMSI) | Vol 7, No. 1, 2016

\section{PENDAHULUAN}

Fenomena mengenai capital intensive dan labour intensive sangat menarik dan dapat menjadi daya tarik investor di Indonesia. Salah satu elemen penting untuk iklim investasi yang baik adalah tenaga kerja. Biaya tenaga kerja yang lebih tinggi dan persyaratan hukum yang ketat untuk mempekerjakan pekerja tetap di Indonesia telah mendorong perusahaan untuk mengalihkan metode produksi mereka ke teknologi dan menggunakan sedikit tenaga kerja. Pemerintah Indonesia memberikan insentif pajak untuk mendorong pertumbuhan perusahaan-perusahaan yang berbasis labour Intensive.

Nilai perusahaan merupakan tujuan utama perusahaan. Nilai perusahaan dapat tercermin dari harga pasar saham yang merupakan penilaian investor terhadap kinerja manajemen perusahaan. Perbedaan hasil penelitian mengenai intensitas industri dan nilai perusahaan menjadi motivasi tersendiri bagi penulis untuk melihat kemungkinan pengaruh perbedaan dari setiap intensitifitas industri di Indonesia dalam kaitannya terhadap pendanaan, kepemilikan manajemen dan pada akhirnya berpengaruh terhadap nilai perusahaan.

Berdasarkan uraian di atas maka yang menjadi rumusan masalah pada penelitian ini adalah sebagai berikut:

1. Apakah capital labour intensive, investasi, kepemilikan manajerial, leverage operasi, dividen dan leverage keuangan secara bersama-sama maupun parsial berpengaruh signifikan terhadap nilai perusahaan?

2. Apakah capital labour intensive, investasi, kepemilikan manajerial, leverage operasi secara bersama-sama maupun parsial berpengaruh signifikan terhadap dividen dan leverage Keuangan?

3. Apakah capital labour intensive, investasi, kepemilikan manajerial, leverage operasi secara bersama-sama maupun parsial berpengaruh signifikan terhadap nilai perusahaan melalui dividen dan leverage keuangan? 


\section{KAJIAN TEORI}

\section{Capital Labour Intensive}

Dalam Perekonomian dibedakan menjadi industri capital intensive dan labour intensive. Capital labour intensive merupakan industri yang membutuhkan investasi besar dalam aset modal untuk memproduksi barang-barang dan jasa, seperti industri mobil. Perusahaan-perusahaan ini memerlukan margin keuntungan besar dan atau biaya pinjaman yang rendah untuk operasional perusahaan.

Labour intensive merupakan industri yang membutuhkan investasi besar dalam tenaga kerja untuk memproduksi barang-barang dan jasa. Industri ini mempunyai produktivitas rendah walaupun menyerap tenaga kerja yang banyak.

\section{Pecking Order Hypotesis}

Pecking Order Hypotesis pertama kali dikenalkan oleh Myer dan Majluf (1984). Berdasarkan Pecking Order Hypotesis, perusahaan lebih mengutamakan dana internal daripada dana eksternal dalam aktivitas pendanaan. Kecukupan dana internal dapat dilihat dari besarnya laba, laba ditahan, atau arus kas. Apabila dana eksternal dibutuhkan, maka perusahaan lebih mengutamakan penggunaan utang daripada ekuitas. Ide dasar Pecking Order Hypotesis yaitu perusahaan membutuhkan dana eksternal hanya apabila dana internal tidak cukup dan sumber dana eksternal yang lebih diutamakan adalah utang daripada emisi saham. Myer dan Majluf (1984) menyatakan bahwa asimetri informasi menyebabkan pendanaan eksternal terlalu mahal bagi perusahaan sehingga perusahaan lebih mengutamakan dana internal daripada dana eksternal.

\section{Kepemilikan Manajerial}

Kepemilikan manajerial (manajerial ownership) merupakan kepemilikan saham oleh manajemen. Kepemilikan manajerial memiliki pengaruh penyejajaran (alligment effect) kepentingan antara pegang saham dan manajer Jensen dan Mackling, (1976). 


\section{Leverage Operasi}

Leverage operasi dapat didefinisikan sebagai timbulnya biaya tetap dalam operasi perusahaan yang dikaitkan dengan penggunaan aktiva tetap. Leverage operasi terjadi pada saat perusahaan menggunakan aktiva tetap dalam operasinya. Untuk mengukur kepekaan leverage operasi digunakan DOL (degree of operating leverage). DOL adalah fungsi dari struktur biaya perusahaan dan biasanya didefinisikan dalam istilah hubungan antara biaya tetap dengan total biaya. Melalui DOL, manajemen dapat mengetahui berapa besar perubahan EBIT yang disebabkan oleh perubahan penjualan.

\section{Dividen}

Damayanti (2006) menunjukan Kebijakan dividen berkaitan dengan keputusan mengenai seberapa besar laba perusahaan yang akan dibagikan kepada pemegang saham atau menjadikan laba tersebut sebagai laba ditahan. Jika dividen yang dibayarkan secara tunai semakin tinggi, maka dana yang tersedia untuk investasi semakin rendah. Kebijakan dividen yang optimal berarti rasio pembayaran dividen yang ditetapkan dengan memperhatikan kesempatan untuk menginvestasikan dana serta berbagai preferensi yang dimiliki para investor mengenai dividen daripada capital gain (Husnan, 1997).

\section{Leverage Keuangan}

Leverage keuangan berkaitan dengan sumber dana yang berasal dari utang, yang akan mengakibatkan biaya tetap tertentu dengan harapan akan meningkatkan keuntungan pemilik modal. Meskipun menimbulkan biaya tetap, perusahaan lebih memilih utang untuk dijadikan sumber pendanaan perusahaan karena biaya transaksi penerbitan utang lebih rendah daripada biaya transaksi penerbitan saham. Hal ini didukung oleh Siregar (2005).

\section{Nilai Perusahaan}

Nilai perusahaan mencerminkan kinerja yang telah dicapai oleh suatu perusahaan dalam melaksanakan kegiatan operasionalnya mulai perusahaan tersebut didirikan sampai dengan saat ini. Meningkatnya nilai perusahaan adalah tujuan yang 
Jurnal Riset Manajemen Sains Indonesia (JRMSI) | Vol 7, No. 1, 2016

sesuai de ngan pemil ik perusah aan, karena dengan meningkatny a nilai peru sahaan, maka kesejahteraan p emilik akan meningkat Sudiyatno (2010).

Dari semua p enjelasan diatas, dapat digambarkan melalu i model ke rangka pemikiran yang disajikan pada g ambar 1 dib awah ini.:

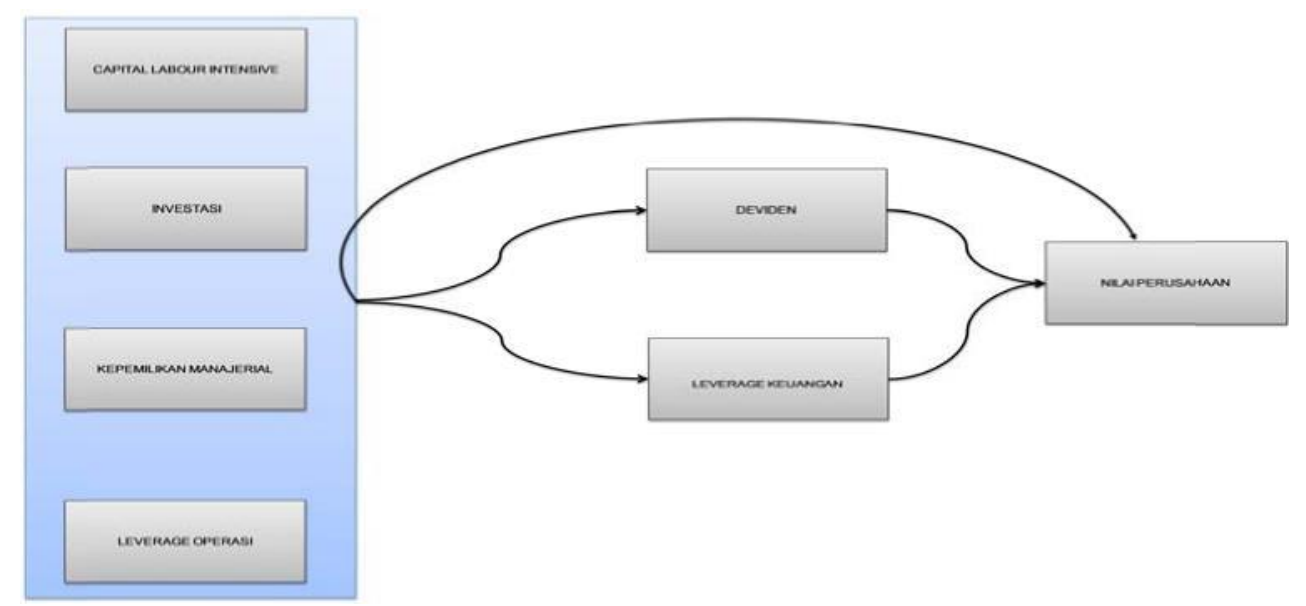

Gamb ar 1: Mod el Kerang ka Konsept ual Pemiki ran

Sumber:Data diolaholehpenelitiBerdasarkankajjan pustaka, review penelitianterdahu lu, dankerangka pemikiran tersebut di atas, hi potesis yan $\mathbf{g}$ diajukan dalam pe nelitian ini adalah sebagai be rikut:

H1 : Capital/labour intensive, investasi, kepemilikan manajerial, leverage operasi, dan dividen serta leverage keuangan diduga secara bersama-sama maupun parsial mempunyai pengaruh terhadap nilai perusahaan di Indonesia.

H2 : capital labour intensive, inventasi, kepemilikkan manajerial, leverage operasi diduga secara bersama-sama maupun parsial mempunyai pengaruh terhadap dividen serta laverage keuangan perusahaan di Indonesia.

H3: capital/laobour intensive, , inventasi, kepemilikkan manajerial, leverage operasi diduga berpengaruh secara tidak langusung terhadap nilai perusahaan melalui dividen serta leverage keuangan. 


\section{METODE PENELITIAN}

Penelitian ini merupakan penelitian hubungan kausal (causal effect), yaitu penelitian yang dirancang untuk menguji pengaruh suatu variabel terhadap variabel. Variabel dalam penelitian ini terdiri dari empat variabel independen yaitu capital labour intensive, investasi, kepemilikan manajerial dan leverage operasi dan tiga variabel dependen yaitu dividen, leverage keuangan dan nilai perusahaan.

Penentuan sampel menggunakan teknik purposive sampling dengan kriteria perusahaan menerbitkan laporan tahunan dari tahun 2003 s.d. 2012. Sampel penelitian yang digunakan adalah 31 perusahaan non keuangan yang terdaftar di Bursa Efek Jakarta. Metode analisis yang digunakan berupa analisis regresi data panel dan analisis jalur (path analysis).

Penelitian ini akan menggunakan model regresi sebagai berikut:

\section{Analisis Regresi Data Panel}

Model Pertama

$N I=\beta_{0}+\beta_{1} C L R+\beta_{2} I N+\beta_{3} K M+\beta_{4} L O+\beta_{5} D E V+\beta_{6} L K+\varepsilon 1$

Model Kedua

$D E V=\beta_{0}+\beta_{7} C L R+\beta_{8} I N+\beta_{9} K M+\beta_{10 L O}+\varepsilon 2$

Model Ketiga

$L K=\beta_{0}+\beta_{11} C L R+\beta 121 \mathrm{~N}+\beta 13 K M+\beta 14 L O+\varepsilon 3$

\section{Model Keempat}

$\mathrm{NI}=\beta_{0}+\beta_{15} \mathrm{DEV}+\beta_{16} \mathrm{LK}+\varepsilon 4$

\section{Analisis Jalur}

Model 1 s.d. 3 menggunakan model 1 s.d. 3 pada analisis regresi data panel di atas.

\section{- Model Keempat}

$\mathrm{NI}=\beta_{0}+\beta_{15} \mathrm{DEV}+\varepsilon 4$

\section{Model Kelima}

$\mathrm{NI}=\beta_{0}+\beta_{16} L K+\varepsilon 5$ 


\section{HASIL DAN PEMBAHASAN}

\section{Statistik Deskriptif}

Hasil perhitungan statistik deskriptif dapat dilihat pada tabel 1 berikut ini:

Tabel 1. Tabel Statistik Deskriptif

\begin{tabular}{lccccccc}
\hline & CLR & IN & KM & LO & DEV & LK & NI \\
Mean & 1.93 & 0.13 & 0.78 & 1.49 & 16.47 & 1.48 & 1.13 \\
Median & 0.89 & 0.12 & 0.01 & 1.03 & 0.33 & 1.43 & 0.83 \\
Maximum & 19.72 & 1.54 & 11.5 & 59.12 & 500.03 & 3.43 & 8.14 \\
Minimum & 0.03 & -0.74 & 0.00 & -61.75 & 0.00 & 0.39 & -0.33 \\
Std. Dev. & 2.90 & 0.20 & 2.28 & 6.40 & 44.45 & 0.31 & 1.18 \\
\hline
\end{tabular}

Sumber : Hasil olah data dengan Eviews 6

\section{Pengujian Persyaratan Analisis Data}

\section{Pemilihan Model Regresi}

Peneliti menggunakan beberapa pertimbangan berikut ini untuk menentukan pendekatan yang digunakan dalam estimasi model regresi (pendekatan common effect, fixed effect atau random effect):

a. Kesesuaian tanda koefisien variabel dengan teori yang digunakan.

b. Uji signifikansi fixed effect (Uji Chow) \& Uji signifikansi fixed effect atau random effect (uji Hausman)

c. Nilai $R^{2}$ dan Adjusted R2

d. Nilai Probabilitas F-statistik dan t-statistik

Berdasarkan 4 (empat) pertimbangan di atas, model regresi yang digunakan dalam penelitian ini adalah model common effect karena model ini mempunyai kesesuaian tanda koefisien variabel dengan teori yang digunakan dan nilai probabilitas F-statistik dan t-statistik untuk beberapa persamaan yang digunakan menunjukkan tingkat signifikan. 
Jurnal Riset Manajemen Sains Indonesia (JRMSI) | Vol 7, No. 1, 2016

\section{Uji Asumsi Klasik}

\section{Uji Multikolonieritas}

\begin{tabular}{llllllll}
\multicolumn{7}{c}{ Tabel 2 Uji Multikolonieritas } \\
\hline & C & I & K & L & DE & L & \\
CL & 1.000000 & 0.086015 & -0.071184 & 0.023659 & -0.050857 & -0.126735 \\
& & & & & & \\
IN & 0.086015 & 1.000000 & 0.015379 & 0.051807 & -0.024212 & -0.014864 \\
& & & & & & \\
KM & -0.071184 & 0.015379 & 1.000000 & 0.107472 & -0.117470 & -0.005998 \\
LO & 0.023659 & 0.051807 & 0.107472 & 1.000000 & 0.000192 & -0.201396 \\
& & & & & & \\
DE & -0.050857 & -0.024212 & -0.117470 & 0.000192 & 1.000000 & 0.005368 \\
V & & & & & & \\
LK & -0.126735 & -0.014864 & -0.005998 & -0.201396 & 0.005368 & 1.000000 \\
& & & & & & \\
NI & 0.245193 & 0.095281 & -0.138405 & -0.013251 & 0.059446 & -0.147415 \\
& & & & & & \\
\hline
\end{tabular}

Sumber: Hasil olah data dengan Eviews 6

Hasil pengujian multikolinearitas pada Tabel 2 di atas, tidak menunjukan adanya korelasi antar variabel independen yang dapat dilihat dari nilai koefisien korelasi tidak ada yang melebihi 0,85 .

\section{Uji Heteroskedastisitas}

Tabel 3 Uji White

\begin{tabular}{lrrrr}
\hline & \multicolumn{4}{c}{ Persamaan (Prob) } \\
& 1 & 2 & 3 & 4 \\
Prob. Chi-Square & 0.9981 & 0.8149 & 0.8162 & 0.9290 \\
\hline
\end{tabular}

Sumber: diolah dari output Eviews 6

Pada Tabel 3 dapat dilihat bahwa nilai probabilitas ( $p$-value) $O b s * R$-squared (Chi-Square) untuk semua persamaan lebih besar dari derajat kepercayaan $(0,05)$, maka dalam hal ini Ho diterima, yang artinya model regresi terbebas dari masalah heteroskedastisitas. 
Jurnal Riset Manajemen Sains Indonesia (JRMSI) | Vol 7, No. 1, 2016

\section{Hasil atau Temuan Penelitian}

Hasil regresi persamaan dengan menggunakan analisis regresi data panel dan analisis jalur adalah sebagai berikut:

Tabel 4. Hasil Regresi dengan Analisis Regresi Data Panel

\begin{tabular}{|c|c|c|c|c|c|c|c|c|c|}
\hline \multirow[b]{2}{*}{ Variable } & \multicolumn{2}{|c|}{ Model 1} & \multicolumn{2}{|c|}{ Model 2} & \multicolumn{2}{|c|}{ Model 3} & \multicolumn{3}{|c|}{ Model 4} \\
\hline & $\begin{array}{l}\text { Co } \\
\text { ef. }\end{array}$ & $\begin{array}{l}\text { Pr } \\
\text { ob. }\end{array}$ & $\begin{array}{l}\text { Co } \\
\text { ef. }\end{array}$ & $\begin{array}{c}\text { Pr } \\
\text { ob. }\end{array}$ & $\begin{array}{l}\text { Co } \\
\text { ef. }\end{array}$ & $\begin{array}{r}\text { Pro } \\
\text { b. }\end{array}$ & $\begin{array}{r}\mathrm{C} \\
\text { oe } \\
\text { f. }\end{array}$ & $\begin{array}{l}\text { Pr } \\
\text { ob. }\end{array}$ & \\
\hline $\mathrm{C}$ & 1.6486 & $\begin{array}{l}0.000 \\
0\end{array}$ & $\begin{array}{r}20.40 \\
48\end{array}$ & $\begin{array}{l}0.000 \\
0\end{array}$ & $\begin{array}{r}1.55 \\
94\end{array}$ & 0.0000 & 1.9443 & & 0.0000 \\
\hline CLR & 0.0887 & $\begin{array}{l}0.000 \\
1\end{array}$ & $\begin{array}{r}- \\
0.894 \\
4\end{array}$ & $\begin{array}{l}0.307 \\
6\end{array}$ & $\begin{array}{r}- \\
0.04 \\
62\end{array}$ & 0.0006 & & & \\
\hline IN & 0.4640 & $\begin{array}{l}0.147 \\
9\end{array}$ & $\begin{array}{r}- \\
3.802 \\
9\end{array}$ & $\begin{array}{l}0.761 \\
5\end{array}$ & 0.145 & 0.1139 & & & \\
\hline KM & $0.0590^{-}$ & $\begin{array}{l}0.040 \\
8\end{array}$ & $\begin{array}{r}- \\
2.401 \\
1\end{array}$ & $\begin{array}{l}0.032 \\
4\end{array}$ & $\begin{array}{r}0.00 \\
02\end{array}$ & 0.9918 & & & \\
\hline LO & 0.0066 & $\begin{array}{l}0.523 \\
2\end{array}$ & $\begin{array}{r}0.108 \\
8\end{array}$ & $\begin{array}{c}0.784 \\
3\end{array}$ & $\begin{array}{r}- \\
0.00 \\
72\end{array}$ & 0.005 & & & \\
\hline DEV & 0.0015 & $\begin{array}{l}0.279 \\
2\end{array}$ & & & & & 0.0016 & & 0.2864 \\
\hline LK & 0.4891 & $\begin{array}{l}0.024 \\
2\end{array}$ & & & & & $\begin{array}{r}- \\
0.5697\end{array}$ & & 0.0091 \\
\hline $\mathrm{R}_{2}$ & 0.09 & & 0.01 & & & 30246 & & 419 & \\
\hline Prob(F-stat) & 0.00 & & 0.23 & & & 00000 & & & \\
\hline
\end{tabular}

Sumber : diolah dari output Eviews 6 
Jurnal Riset Manajemen Sains Indonesia (JRMSI) | Vol 7, No. 1, 2016

Tabel 5. Hasil Regresi dengan Analisis Jalur

\begin{tabular}{|c|c|c|c|c|c|c|c|c|c|c|}
\hline \multirow[b]{2}{*}{ Variable } & \multicolumn{2}{|c|}{ Model 1} & \multicolumn{2}{|c|}{ Model 2} & \multicolumn{2}{|c|}{ Model 3} & \multicolumn{2}{|c|}{ Model 4} & \multicolumn{2}{|c|}{ Model 5} \\
\hline & Coef. & $\begin{array}{l}\text { Pr } \\
\text { ob }\end{array}$ & Coef. & $\begin{array}{l}\text { Pr } \\
\text { ob }\end{array}$ & $\begin{array}{l}\text { Coe } \\
\text { f. }\end{array}$ & $\begin{array}{l}\text { Pr } \\
\text { ob }\end{array}$ & $\begin{array}{l}\text { Coe } \\
\text { f. }\end{array}$ & $\begin{array}{l}\operatorname{Pr} \\
\mathrm{ob}\end{array}$ & $\begin{array}{l}\text { Coef } \\
\text {. }\end{array}$ & $\begin{array}{l}\text { Pr } \\
\text { ob }\end{array}$ \\
\hline CLR & 0.218 & 0.000 & -0.058 & $\begin{array}{l}\cdot \\
0.00 \\
0\end{array}$ & $\begin{array}{l}- \\
0.12 \\
2\end{array}$ & $\begin{array}{l}\quad \cdot \\
0.03 \\
0\end{array}$ & & . & & . \\
\hline IN & 0.080 & 0.147 & -0.018 & $\begin{array}{l}0.30 \\
7\end{array}$ & $\begin{array}{l}0.00 \\
6\end{array}$ & $\begin{array}{l}0.91 \\
7\end{array}$ & & & & \\
\hline KM & -0.114 & 0.040 & -0.123 & $\begin{array}{l}0.75 \\
1\end{array}$ & $\begin{array}{l}0.00 \\
7\end{array}$ & $\begin{array}{l}0.90 \\
6\end{array}$ & & & & \\
\hline LO & -0.036 & 0.523 & 0.016 & $\begin{array}{l}0.03 \\
2\end{array}$ & $\begin{array}{l}- \\
0.20 \\
0\end{array}$ & $\begin{array}{l}0.00 \\
0\end{array}$ & & & & \\
\hline DEV & 0.060 & 0.278 & & & & & & & & \\
\hline LK & -0.127 & 0.024 & & & & & & & & \\
\hline DEV' & & & & & & & $\begin{array}{l}0.05 \\
9\end{array}$ & $\begin{array}{r}0 . \\
0 \\
3\end{array}$ & & \\
\hline $\mathrm{LK}^{\prime}$ & & & & & & & & & $\begin{array}{l}- \\
0.14 \\
7\end{array}$ & $\begin{array}{r}0 . \\
06 \\
9\end{array}$ \\
\hline $\mathrm{R}_{2}$ & 0.100 & & 0.018 & & 0.056 & & 0.004 & & 0.022 & \\
\hline Prob(F-stat) & 0.000 & & 0.238 & & 0.002 & & 0.297 & & 0.009 & \\
\hline
\end{tabular}

Sumber : diolah dari output Eviews 6 


\section{HASIL PENELITIAN DAN PEMBAHASAN}

Dari hasil pengujian hipotesis di atas, dapat disimpulkan bahwa CLR, IN, KM, LO, DEV, dan LK secara bersama-sama berpengaruh signifikan sebesar $9.94 \%$ terhadap NI.

Nilai koefisien variabel CLR menunjukkan arah pengaruh positif dengan nilai probabilitas 0.000 yang berarti CLR berpengaruh positif signifikan terhadap NI. Hal ini menunjukan semakin tinggi perusahaan berbasis capital intensive semakin tinggi nilai perusahaan tersebut di mata investor. Keunggulan perusahaan yang berbasis padat modal yaitu kecenderungan untuk mendapatkan keuntungan yang stabil dan baik. Tetapi industri ini sangat bergantung dengan kualitas sumber daya manusia karena terkait dengan pemanfaatan teknologi.

Nilai koefisien variabel IN menunjukkan arah pengaruh positif dengan nilai probabilitas 0.1479 yang berarti IN tidak berpengaruh positif signifikan terhadap NI. Nilai perusahaan sangat dipengaruhi oleh peluang investasi. Efek langsung keputusan investasi terhadap nilai perusahaan merupakan hasil yang diperoleh dari aktivitas investasi.

Nilai koefisien variabel KM menunjukkan arah pengaruh negatif dengan nilai probabilitas 0.0408 yang berarti KM berpengaruh negatif signifikan terhadap NI. Hal ini tidak sesuai dengan teori bahwa Studi empiris menjelaskan bahwa terdapat hubungan non-linear antara kepemilikan manajerial dengan nilai perusahaan Jensen dan Meckling (1996).

Nilai koefisien variabel LO menunjukkan arah pengaruh negatif dengan nilai probabilitas 0.5232 yang berarti LO tidak berpengaruh negatif signifikan terhadap NI. Jika perusahaan mempunyai Degree of Operating Leverage ( DOL ) yang tinggi, tingkat penjualan yang tinggi akan menghasilkan pendapatan yang tinggi Mardiansyah (2012).

Nilai koefisien variabel DEV menunjukkan arah pengaruh positif dengan nilai probabilitas 0.2792 yang berarti DEV berpengaruh positif terhadap NI, namun tidak 
signifikan. Hal ini sesuai dengan hasil penelitian oleh Fenandar dan Surya (2012) menemukan hasil bahwa adanya pengaruh positif dan signifikan antara kebijakan dividen terhadap nilai perusahaan. Fama dan French (1988) menemukan bahwa investasi yang dihasilkan oleh kebijakan dividen memiliki informasi yang positif terhadap nilai perusahaan.

Berdasarkan hasil penelitian dapat dilihat bahwa investor tidak melihat dividen sebagai indikasi kinerja manajer yang dapat meningkatkan kinerja dan nilai perusahaan.

Nilai koefisien variabel LK menunjukkan arah pengaruh negatif dengan nilai probabilitas 0.0242 yang berarti LK berpengaruh negatif terhadap NI. Hasil penelitian ini sesuai dengan penelitian yang dilakukan oleh Nurchanifia (2012) yang menyatakan pengaruh negatif antara leverage keuangan terhadap nilai perusahaan.

Hasil pengujian hipotesis di atas juga menunjukkan bahwa CLR, IN, KM, dan LO secara bersama-sama tidak berpengaruh signifikan sebesar $1.78 \%$ terhadap DEV.

Tanda koefisien variabel CLR adalah negatif dengan probabilitas 0.3076, yang artinya bahwa CLR tidak berpengaruh negatif signifikan terhadap DEV.

Tanda koefisien variabel IN adalah negatif dengan probabilitas 0.7615 , yang artinya bahwa IN tidak berpengaruh negatif signifikan terhadap DEV. Hal ini sesuai dengan penelitian Fama dan French (2000) dalam Damayanti (2006) menyatakan bahwa perusahaan yang profitabel dan yang mempunyai keperluan investasi lebih sedikit akan memiliki dividend payout yang lebih tinggi sebaliknya mereka juga menyatakan bahwa dengan memiliki market leverage yang lebih sedikit dengan long term dividend payout yang lebih rendah, meskipun dividen tidak bervariasi untuk mengakomodasikan variasi investasi jangka pendek. Variasi investasi dan earnings jangka pendek sebagian besar diserap oleh utang. Hal ini konsisten dengan prediksi pecking order theory.

Tanda koefisien variabel KM adalah negatif dengan probabilitas 0.0324, yang artinya bahwa KM berpengaruh negatif signifikan terhadap DEV. Hasil penelitian di 12 
atas sesuai dengan hasil penelitian oleh Chen dan Steiner (1999) dalam Nasir (2006) menyatakan bahwa kepemilikan manajerial dan kebijakan utang memiliki hubungan negatif. Hal ini dikarenakan adanya faktor substitusi antara keduanya. Pada saat kepemilikan manajerial meningkat, manajer akan menurunkan nilai utang untuk menurunkan risiko dan biaya keagenan.

Nilai koefisien variabel LO menunjukkan arah pengaruh positif dengan nilai probabilitas 0.7843 yang berarti LO tidak berpengaruh positif signifikan terhadap DEV. Hal ini tidak sesuai dengan teori, perusahaan dengan leverage operasi yang tinggi akan cenderung lebih berhati-hati dalam menggunakan utang untuk pendanaan, karena utang akan menambah beban tetap bagi perusahaan berupa biaya bunga dan pokok angsuran, sehingga hal ini dapat meningkatkan risiko terjadinya financial distress yaitu perusahaan tidak mampu memenuhi kewajibannya.

Hasil pengujian hipotesis di atas juga menunjukkan bahwa CLR, IN, KM, dan LO secara bersama-sama berpengaruh signifikan sebesar $33.02 \%$ terhadap LK.

Tanda koefisien variabel CLR adalah negatif dengan probabilitas 0.0006, yang artinya bahwa CLR berpengaruh negatif signifikan terhadap LK. Hasil penelitian ini sesuai dengan Qian (2002) yang menyatakan hubungan negatif dengan leverage.

Tanda koefisien variabel IN adalah positif dengan probabilitas 0.1139, yang artinya bahwa IN tidak berpengaruh positif signifikan terhadap LK. Fama,et al. (2000) dalam Yustiningsih (2002) menyatakan bahwa keseimbangan biaya pendanaan mendorong perusahaan yang mempunyai investasi besar cenderung mempunyai leverage yang tinggi. Semakin besar kesempatan investasi, maka semakin besar perusahaan menggunakan dana yang dimilikinya untuk investasi. Sesuai dengan prediksi $\mathrm{POH}$, dana ekternal yang diutamakan oleh perusahaan adalah utang.

Tanda koefisien variabel KM adalah positif dengan probabilitas 0.9918, yang artinya bahwa KM tidak berpengaruh positif signifikan terhadap LK. Jensen et al. (1992) menyatakan bahwa terdapat hubungan negatif antara persentase kepemilikan manajer dengan debt ratio. 
Jurnal Riset Manajemen Sains Indonesia (JRMSI) | Vol 7, No. 1, 2016

Nilai koefisien variabel LO menunjukkan arah pengaruh negatif dengan nilai probabilitas 0.005 yang berarti kurs berpengaruh negatif signifikan terhadap LK. Perusahaan dengan leverage operasi yang tinggi akan cenderung berhati-hati dalam menggunakan utang untuk pendanaan, karena utang akan menambah beban tetap bagi perusahaan berupa beban bunga pinjaman. Hal ini sesuai dengan penelitian Ferri dan Jones (1979) yang menguji hubungan antara leverage keuangan dan leverage operasi.

Berdasarkan pengujian hipotesis ketiga di atas, bahwa variabel DEV dan LK dengan secara bersama-sama berpengaruh signifikan terhadap NI karena nilai probabilitas F-statistik sebesar 0.01921 lebih kecil dibandingkan tingkat signifikan sedangkan nilai probabilitas t-statistik DEV tidak menunjukkan tingkat signifikan sehingga variabel LK merupakan variabel mediasi.

Pengujian DEV dan LK sebagai variabel mediasi juga dilakukan dengan menggunakan analisis jalur. Hasil analisis jalur menunjukkan pengaruh langsung variabel CLR, IN, KM, dan LO terhadap NI lebih besar daripada pengaruh tidak langsung variabel CLR, IN, KM, dan LO terhadap NI melalui DEV maupun LK.

Tabel 4.6 Pengaruh Langsung dan Tidak Langsung

\begin{tabular}{|l|c|c|c|}
\hline \multirow{2}{*}{ Pengaruh } & Langsung & \multicolumn{2}{c|}{ Tidak Langsung } \\
\cline { 3 - 4 } & & Melalui DEV & Melalui LK \\
\hline CLR terhadap NI & 0.218 & -0.00342 & 0.01793 \\
\hline IN terhadap NI & 0.080 & -0.00106 & -0.00088 \\
\hline KM terhadap NI & -0.114 & -0.00726 & -0.00103 \\
\hline LO terhadap NI & -0.036 & 0.00094 & 0.02940 \\
\hline
\end{tabular}

Sumber: Diolah dari Hasil Analisis Jalur

Hasil tersebut menunjukkan bahwa CLR, IN, KM dan LO tidak berpengaruh terhadap NI melalui DEV dan LK sebagai variabel mediasi. 


\section{KESIMPULAN DAN SARAN}

\section{Kesimpulan}

Berdasarkan penelitian ini maka dapat diambil kesimpulan sebagai berikut:

1. Capital labour intensive, investasi, kepemilikan manajerial, Ieverage operasi, dividen dan leverage keuangan secara bersama-sama berpengaruh signifikan terhadap nilai perusahaan.

2. Capital labour intensive, investasi, kepemilikan manajerial dan Ieverage operasi secara bersama-sama dan parsial tidak berpengaruh signifikan terhadap dividen perusahaan. capital labour intensive, investasi, kepemilikan manajerial dan Ieverage operasi secara bersama-sama dan parsial berpengaruh signifikan terhadap leverage keuangan perusahaan.

3. Hasil analisis jalur menunjukkan pengaruh langsung variabel capital labour intensive, investasi, kepemilikan manajerial dan Ieverage operasi terhadap nilai perusahaan lebih besar daripada pengaruh tidak langsung variabel capital labour intensive, investasi, kepemilikan manajerial dan Ieverage operasi terhadap nilai perusahaan melalui dividen maupun leverage keuangan.

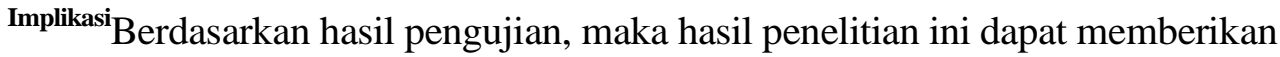
kontribusi implikasi teoritis sebagai berikut:

1. Capital labour intensive, investasi, kepemilikan manajerial, Ieverage operasi, dividen dan leverage keuangan mempunyai pengaruh terhadap nilai perusahaan.

2. Analisis pengaruh capital labour intensive, investasi, kepemilikan manajerial dan Ieverage operasi terhadap nilai perusahaan lebih baik dilakukan secara langsung daripada menggunakan dividen dan leverage keuangan sebagai variabel mediasi. 
Jurnal Riset Manajemen Sains Indonesia (JRMSI) | Vol 7, No. 1, 2016

Adapun implikasi kebijakan dari hasil penelitian ini adalah sebagai berikut:

1. Pihak akademisi dapat mendorong penelitian lebih lanjut mengenai faktorfaktor yang mempengaruhi nilai perusahaan selain faktor financial yaitu faktor intensifitas industri di Indonesia.

2. Bagi manajemen, penelitian ini memberikan bukti pentingnya pengelolaan risiko yang dapat dilihat dengan leverage sebagai salah satu upaya dalam meningkatkan nilai perusahaan.

3. Bagi pemerintah, penelitian ini memberikan bukti bahwa intensitifitas industri dengan perusahaan yang berbasis padat modal mempunyai nilai perusahaan yang lebih baik dibandingkan industri padat karya.

\section{Saran}

Berdasarkan hasil penelitian, peneliti menyarankan hal-hal sebagai berikut:

1. Bagi peneliti dapat memperluas sektor yang diteliti menjadi semua sektor industri sehingga dapat membedakan perbedaan pengaruh capital labour intensive, investasi, kepemilikan manajerial, Ieverage operasi, dividen dan leverage terhadap nilai perusahaan sehingga dapat memberikan hasil yang lebih baik. Selain itu juga dapat dilibatkan faktor ekonomi makro seperti inflasi, tingkat suku bunga, nlai tukar dan pertumbuhan ekonomi sebagai variabel mediasi terkait intensifitas industri di Indonesia.

2. Pihak manajemen, penelitian ini diharapkan dapat dijadikan sebagai bahan masukan dan pertimbangan bagi manajer perusahaan dalam memilih fokus perusahan, investasi dan pendanaan bagi perusahaan.

3. Bagi pemerintah, penelitian ini dapat memberikan masukan dalam membuat kebijakan yang lebih komprehensif mengenai intensifitas industri baik dari sisi perpajakan maupun penyediaan insfratruktur yang mendukung perkembangan industri padat karya. Hal tersebut jika dilakukan dapat meningkatkan daya saing perusahaan berbasis padat karya dan berkontribusi dalam meningkatkan pemerataan pendapatan bagi penduduk. 


\section{DAFTAR PUSTAKA}

Alexander, Gordon J., William F Sharpe and Jeffrey V. Bailey. Fundamentals Of Investment.3rd ed. New Jersey: Prentice-Hall,Inc, 2007.

Allen. "The Pecking Order Hypothesis: Australian Evidence". Applied Financial Economics. Vol. 3: 101-112, 1993.

Amihud, Yakov and Baruch Lev. "Risk Reduction as a Managerial Motive for Conglomerate Mergers". Bell Journal of Economics. Vol. 12, pg. 605617, 1981.

Baskin. “An Empirical Investigation of Pecking Order Hypothesis.” Financial Management. Spring:26-35, 1989.

Bloom, Lambrechts, Roux. "Distinguishing Between Capital Intensive And Labour Intensive Enterprises Listed In The Industrial Sector Of JSE". Interdiciplinary Journal of Contemporary Research in Business, Vol.7, No.04. Matieland: Applied Science University of Stellenbosch, 1998.

Bloom, Lambrechts, Roux. "Pattern In Financial Performance Indicators Of Capital And Labour Intensive Enterprises During An Upswing And A Decline In The Economic cycle". Interdiciplinary Journal of Contemporary Research in Business, Vol.14, No.02. Matieland: Applied Science University of Stellenbosch, 2000.

Bond, S., Van Reenen, J.2006. Microeconometric models of investment and employment. In: Heckman J., Leamer E. (Eds), Handbook of Econometrics, Vol. 6, Elsevier, North-Holland, 2006.

Budiyanti, "Pengaruh Investasi, Kepemilikan Manajerial dan Leverage Operasi terhadap Hubungan Interpedensi antara Kebijakan Dividen dengan Kebijakan Leverage Keuangan", Thesis(Yogyakarya:YKPN, 2008).

Carpenter, R.E., Guariglia, A., Cash flow, investment and investment opportunities: new tests using UK panel data. Journal of Banking and Finance 32, 1894-1906, 2008.

Clay, Darin G. "Instituional Ownership, CEO Incentive, and Firm Value", Dissertation of Doctor of Philosophy The University of Chicago, Chicago, Illinois, 2001.

Chung, K.H., \& Pruitt, S.W. A simple approximation of Tobin's q. Financial Management, 23(3): 70-74, 1994.

Damayanti. "Analisis Pengaruh Investasi, Likuiditas, Profitabilitas, Pertumbuhan Perusahaan dan Ukuran Perusahaan terhadap Kebijakan Dividen Payout Ratio". Jurnal Akuntansi dan Keuangan. Vol. 5. No. 1, 2006. 
Darminto. "Pengaruh Profitabilitas, Likuiditas, Struktur Modal Dan Struktur Kepemilikan Saham Terhadap Kebijakan Dividen”. Jurnal Ilmu-Ilmu Sosial Vol. 20, 2008.

Dermawan E.S., "Faktor-faktor Penentu Kebijakan Pembayaran Dividen pada Perusahaan-perusahaan yang Go Publik di BEJ tahun 1994”. Thesis S2. Msi. UGM,1997.

Easterbrook, F. Two agency-cost explanations of dividends. American Economic Review 74: 650-659,1984.

Eugene F. Brigham dan Joel F. Houston. Dasar-Dasar Manajemen

Keuangan. Buku 1. Jakarta: Salemba Empat, 1991.

Ghozali, Imam. Aplikasi Analisis Multivariate Dengan Program SPSS. Edisi ke-6. Semarang : BP Universitas Diponegoro, 2012.

Hubbard, G. Capital market imperfections and investment. Journal of Economic Literature 35, 1998.

Husnan, S. Manajemen Keuangan: Teori dan Penerapan (Keputusan Jangka Pendek), edisi 4, BPFE-UGM. Yogyakarta, 1997.

Husnan, Suad dan Pudjiastuti, Enny. Dasar-Dasar Teori Portofolio dan Analisis Sekuritas, Edisi 4, (Yogyakarta: BPFE-UGM, 2007).

Ismiyanti dan Hanafi "Kepemilikan Manajerial, Kepemilikan Institusional, Risiko, Kebijakan Utang dan Kebijakan Dividen. Simposium Nasional Akuntansi 6,16-17 Oktober, Surabaya, 2003.

Ismiyanti dan Hanafi "Analisis Persamaan Simultan Kepemilikan Manajerial, Kepemilikan Institusional, Risiko, Kebijakan Utang dan Kebijakan Dividen dalam perspektif teori keagenan. Simposium Nasional Akuntansi 9, 23-26 Agustus, Padang, 2006.

Jensen dan Meckling. Theory of the Firm: Managerial Behavior Agency Cost and Ownership Structure, Journal of Financial Economic, Oktober, 1976, V.3, No. 4, 1976.

Jogiyanto Hartono dan Chendrawati. "ROA and EVA: A Comparative Empirical Study", Gadjah Mada International Journal of Business, Vol. 1, No. 1, pp. 45-54, 1999.

Jonathan Sarwono. Path Analysis dengan SPSS: Teori, Aplikasi, Prosedur Analisis untuk Riset Skripsi, Tesis dan Disertasi, (Jakarta: Penerbit PT Elex Media Komputindo, 2012).

Lang, Larry H.P and Rena M. Stulz. "Tobin's Q, Corporate Diversification, and Firm Performance". Journal of Political Economy, Vol. 102, pg. 1248-1280, 1994.

Lindenberg, Eric B., and Stephen A. Ross. "Tobin's q ratio and industrial organization”, Journal of Business 54, 1-32, 1981.

Lina, Darmayanti, "Pengaruh Kepemilikan Manajerial dan Kinerja Keuangan terhadap kebijakan Dividen dan Nilai Perusahaan", Thesis(Denpasar:Universitas Udayana, 2012). 
Lina, Joni. "Faktor-Faktor Yang Mempengaruhi Struktur Modal". Jurnal Bisnis dan Akuntansi Vol. 12, 2010.

Mahadwarta, The Association of Managerial Ownership with Dividend Policy and Leverage Policy: A Logit Model. Proceeding Simposium Surviving Strategies to Cope with the Future, September 13th,(Universitas Atmajaya, Yogyakarta, 2002).

Mahadwartha dan Hartono. 2002. Empirical Test of Balancing Model of Agency Cost, Contracting Model of Agency Theory, Collateral, and Growth Hypothesis in Indonesian Capital Market. Simposium Nasional Akuntansi, 6 September, Universitas Diponegoro, Semarang: 1-29

Mardiansyah, "Pengaruh Profitabilitas Operating Leverage terhadap Struktur Modal Pada Perusahaan Makanan dan Minuman" (Padang: Universitas Negeri Padang, 2012).

Mike. Memanfaatkan EVA untuk Menilai Perusahaan di Pasar Modal Indonesia, Usahawan No. 4, Th. XXVI, Hal. 18-21, 1997.

Moh'd M.A.,L.G. Perry, and J.N. Rimbey. "The Impact of Ownership Structure on Corporate Debt Policy: Time series Cross-Sectional Analysis”, Financial Review, August, Vol. 33, 85-99, 1998.

Morck, R., A. Shleifet dan R.W. Vishny. 1988. Management Ownership and Market Valuation: An Empirical Analysis. Journal of Financial Economics, Vol.20, hal.293-315.

Myer dan Majluf. "Corporate Financing and Investment Decision when Firm have Information Investors do not Have", Journal of Finance Economics 13, 187-221, 1984.

Nasir dan Putri. “Analisis Persamaan Simultan Kepemilikan Manajerial, Kepemilikan Institusional, Risiko, Kebijakan Utang dan Kebijakan Dividen dalam perspektif teori keagenan". Simposium Nasional Akuntansi 9, 23-26 Agustus, Padang, 2006.

Nuraina, Elva. "Pengaruh Kepemilikan Institusional Dan Ukuran Perusahaan Terhadap Kebijakan Hutang Dan Nilai Perusahaan". Jurnal Bisnis dan Ekonomi, ISSN:1412-3126, Madiun: IKIP PGRI, 2012.

Nurchanifia, "Analisis Pengaruh Financial Leverage terhadap Nilai Perusahaan", (Surabaya:STIE Perbanas, 2012).

Riduwan dan Sunarto. Pengantar Statistika Untuk Penelitian Pendidikan, Sosial, Ekonomi Komunikasi, dan Bisnis. Bandung: Alfabeta, 2010.

Riyanto, Bambang. Dasar-dasar Pembelajaran Perusahaan, Edisi 4,(Yogyakarta:BPFE UGM,1997).

Rozeff, M.S. "Gwoth, beta and agency cost as determinants of dividend payout ratios". Journal of Financial Research 5: 249-259, 1982.

Ross, Stephen A., Randolph W. Westerfield, dan Bradford D. Jordan. Fundamentals of Corporate Finance: Alternate Edition. McGraw-Hill, 2010. 
Jurnal Riset Manajemen Sains Indonesia (JRMSI) | Vol 7, No. 1, 2016

Sekaran, Uma. "Metodologi Penelitian untuk Bisnis", Edisi 4, Buku 2. Jakarta: Penerbit Salemba Empat: 2006.

Shin, Hyun han dan Rene m. Stulz. "Shareholder wealth and Firm Risk". NBER Dice Center Working Paper No.19, 2000.

Siregar. "Hubungan antara dividen, leverage keuangan dan investasi". Jurnal akuntansi dan manajemen. Vol.16. No 3 (desember): 219-230, 2005.

Soebiantoro, Ugi dan Sujoko. "Pengaruh Struktur Kepemilikan Saham, Leverage, Faktor Intern Dan Faktor Ekstern Terhadap Nilai Perusahaan". Jurnal Manajemen dan Kewirausahaan Vol. 09, 2007.

Sofyan Syafri Harahap, “Analisis Kritis atas Laporan Keuangan”, (Jakarta: PT RajaGrafindo Persada, 2007).

Suad Husnan, "Dasar-dasar Teori Portofolio dan Analisis Sekuritas", Ed.3. Yogyakarta: UPP AMP YKPN, 2001.

Subramanian, Krishnamurthy. "Firm Boundaries And Financing Choices In Human Capital Intensive Firm". International Journal. Chicagos:The University Of Chicago, 2005.

Sudiyatno, Peran Kinerja Perusahaan Dalam Menentukan Pengaruh Faktor Fundamental Makroekonom, Risiko Sistematis, dan Kebijakan Perusahaan Terhadap Nilai Perusahan (Semarang: Universitas Dipenogoro, 2010).

Sugiyono, Metode Penelitian Kuantitatif Kualitatif dan $R \& D$. (Bandung: Penerbit Alfabeta, 2010).

Suliyanto. Ekonometrika Terapan: Teori \& Aplikasi dengan SPSS. (Yogyakarta: Penerbit Andi, 2011).

Sujoko dan Ugy Subiantoro, "Pengaruh Struktur Kepemilikan Saham, Leverage, Faktor Intern Dan Faktor Ekstern Terhadap Nilai Perusahaan" Jurnal Manajemen dan Kewirausahaan, Vol. 9, No. 1, 4148, 2007.

Tri Gunarsih. Pengaruh Struktur Kepemilikan dalam Corporate Governance dan Strategi Diversifikasi Terhadap Kinerja Perusahaan, Disertasi, Universitas Gadjah Mada Yogyakarta, 2003.

Widarjono, Agus. Ekonometrika Pengantar dan Aplikasinya. Yogyakarta: Penerbit Ekonisia Fakultas Ekonomi UII, 2009.

Wijaya, Lihan dan Bandi, "Pengaruh Keputusan Investasi, Keputusan Pendanaan, dan Kebijakan Dividen terhadap Nilai Perusahaan. Simposium Nasional Akuntansi 13, Purwokerto, 2010.

Winarno, Wing Wahyu. Analisis Ekonometrika dan Statistika dengan Eviews, edisi kedua. Yogyakarta: Unit Penerbit dan Percetakan Sekolah Tinggi Ilmu Manajemen YKPN, 2009.

Wolfe, J and Sauaia, A.C. "The Tobin q as a Company Performance Indicator, Developments in Business Simulation and Experiential Learning", Volume 30, 2003. 
Jurnal Riset Manajemen Sains Indonesia (JRMSI) | Vol 7, No. 1, 2016

Yamin, Sofyan, Lien A. Rachmah, dan Heri Kurniawan. Regresi dan Korelasi dalam Genggaman Anda (Aplikasi dengan Software SPSS, Eviews, Minitab, dan Statgraphics). Jakarta: Penerbit Salemba 4, 2011. Qian, Yiming. "Financing Human-Capital-Intensive_Firms".International Journal. New York:The University Of New York, 2002.

\author{
Website \\ http://finance.detik.com (diakses tanggal 1 Januari 2014). \\ http://id.kemendag.go.id (diakses tanggal 9 Oktober 2013). \\ http://www.idx.go.id \\ http://www.kompas.com (diakses tanggal 28 Mei 2010). \\ http://www.kemenperin.go.id
}

